\title{
Molecular detection of Acanthamoeba spp., Naegleria fowleri and Vermamoeba (Hartmannella) vermiformis as vectors for Legionella spp. in untreated and solar pasteurized harvested rainwater
}

Penelope H. Dobrowsky', Sehaam Khan ${ }^{2}$, Thomas E. Cloete ${ }^{1}$ and Wesaal Khan ${ }^{1 *}$

\begin{abstract}
Background: Legionella spp. employ multiple strategies to adapt to stressful environments including the proliferation in protective biofilms and the ability to form associations with free-living amoeba (FLA). The aim of the current study was to identify Legionella spp., Acanthamoeba spp., Vermamoeba (Hartmannella) vermiformis and Naegleria fowleri that persist in a harvested rainwater and solar pasteurization treatment system.
\end{abstract}

Methods: Pasteurized $\left(45^{\circ} \mathrm{C}, 65^{\circ} \mathrm{C}, 68^{\circ} \mathrm{C}, 74^{\circ} \mathrm{C}, 84^{\circ} \mathrm{C}\right.$ and $\left.93^{\circ} \mathrm{C}\right)$ and unpasteurized tank water samples were screened for Legionella spp. and the heterotrophic plate count was enumerated. Additionally, ethidium monoazide quantitative polymerase chain reaction (EMA-qPCR) was utilized for the quantification of viable Legionella spp., Acanthamoeba spp., V. vermiformis and $\mathrm{N}$. fowleri in pasteurized $\left(68{ }^{\circ} \mathrm{C}, 74{ }^{\circ} \mathrm{C}, 84^{\circ} \mathrm{C}\right.$ and $\left.93^{\circ} \mathrm{C}\right)$ and unpasteurized tank water samples, respectively.

Results: Of the 82 Legionella spp. isolated from unpasteurized tank water samples, Legionella longbeachae (35\%) was the most frequently isolated, followed by Legionella norrlandica (27 \%) and Legionella rowbothamii (4\%). Additionally, a positive correlation was recorded between the heterotrophic plate count vs. the number of Legionella spp. detected $(\rho=0.710, P=0.048)$ and the heterotrophic plate count vs. the number of Legionella spp. isolated ( $\rho=0.779, P=0.0028$ ) from the tank water samples collected. Solar pasteurization was effective in reducing the gene copies of viable $V$. vermiformis (3-log) and $N$. fowleri (5-log) to below the lower limit of detection at temperatures of $68-93{ }^{\circ} \mathrm{C}$ and $74-93{ }^{\circ} \mathrm{C}$, respectively. Conversely, while the gene copies of viable Legionella and Acanthamoeba were significantly reduced by 2 - $\operatorname{logs}(P=0.0024)$ and $1-\log (P=0.0015)$ overall, respectively, both organisms were still detected after pasteurization at $93^{\circ} \mathrm{C}$.

Conclusions: Results from this study indicate that Acanthamoeba spp. primarily acts as the vector and aids in the survival of Legionella spp. in the solar pasteurized rainwater as both organisms were detected and were viable at high temperatures $\left(68-93^{\circ} \mathrm{C}\right)$.

Keywords: Rainwater harvesting, Solar pasteurization, Legionella, Acanthamoeba, Vermamoeba, Naegleria

\footnotetext{
* Correspondence: wesaal@sun.ac.za

${ }^{1}$ Department of Microbiology, Faculty of Science, Stellenbosch University,

Private Bag X1, Stellenbosch 7602, South Africa

Full list of author information is available at the end of the article
} 


\section{Background}

The demand on fresh water supplies is intensifying as a result of an increase in the world's population and urbanization, coupled with the negative effects of climate change [1-3]. Domestic rainwater harvesting systems can be utilized to augment existing surface- and groundwater supplies and in many countries it is utilized as a primary potable water source as well as for domestic and irrigation purposes. Several studies have however, highlighted that rainwater may become contaminated, especially during the harvesting process when debris, animal excreta, dust and leaves, which have accumulated on the roof catchment surface, are washed into the rainwater storage tank [4-6]. It is thus recommended that harvested rainwater is disinfected as numerous pathogens, including those that are opportunistic in nature, have previously been detected in this water source and are of a human health concern [7-12].

Dobrowsky et al. [13], indicated that a closed-coupled solar pasteurization system operating at temperatures greater than $72{ }^{\circ} \mathrm{C}$ can be utilized to treat harvested rainwater as the level of heterotrophic bacteria, Escherichia $\operatorname{coli}($ E. coli) and total coliforms were reduced to below the detection limit and were within the respective drinking water guidelines [14-16]. However, PCR assays confirmed the presence of Yersinia spp., Legionella spp., and Pseudomonas spp., at temperatures greater than $72{ }^{\circ} \mathrm{C}$, with Legionella spp. persisting at temperatures greater than $90{ }^{\circ} \mathrm{C}$. A follow-up study performed by Reyneke et al. [17], indicated that Legionella spp. may be entering a viable but non-culturable (VBNC) state as intact Legionella cells were detected at temperatures of up to $95{ }^{\circ} \mathrm{C}$ using ethidium monoazide (EMA) quantitative PCR (EMA-qPCR).

Legionella spp. exhibit a number of mechanisms enabling them to withstand environmental stresses such as heat treatment. These include associations with at least 20 protozoan hosts including Acanthamoeba spp., Naegleria spp., Vermamoeba (Hartmannella) vermiformis and Vahlkampfia spp. and two species of ciliated protozoa, including Tetrahymena spp. and Cyclidium spp. [18]. Their association with free-living amoeba (FLA) is especially effective as the amoeba host provides nutrients including, amino acids for the proliferation of Legionella spp. and a protective environment when Legionella spp. are enclosed in the cysts of the amoeba species $[19,20]$.

Of the genera belonging to the FLA, Acanthamoeba spp., Naegleria fowleri and $V$. vermiformis are the most frequently isolated from water samples [21-23], including samples from hot water systems [19, 24, 25]. Moreover, Acanthamoeba spp. and $N$. fowleri are associated with human and animal infections, including amoebic keratitis and severe brain pathologies [26-29]. The life-cycles of these FLAs are then divided into two stages. First, in the form of a vegetative trophozoite, the organism is able to feed and replicate. Secondly, a cyst is formed under unfavourable environmental conditions and this allows the organism to withstand nutrient starvation, heat, cold, desiccation and biocidal treatments [29-31]. Although there is limited data regarding FLA resistance to various disinfection procedures, they are a potential risk to public health not only because of the transmission of the protozoa themselves, but because they harbour a range of microbial pathogens including Legionella spp., Listeria monocytogenes, Pseudomonas aeruginosa and Mycobacterium spp., amongst other species [29, 32, 33].

Generally during the process of phagocytosis, the amoeba will engulf avirulent bacterial cells and form a phagosome. The phagosome then fuses with the lysosome, containing lysozymes, which degrade the bacterial cells [34]. Although there are differences in host-cell trafficking processes amongst L. pneumophila, L. micdadei and $L$. longbeachae, virulent Legionella spp. have the ability to halt the phagosome-lysosomal degradation pathway of the amoeba. This implies that the phagosome (containing the Legionella) does not undergo sequential maturation and therefore does not ultimately fuse with degradative lysosomes $[35,36]$. The Legionella instead form a Legionella containing vacuole by recruiting secretory vesicles from the endoplasmic reticulum exit sites and mitochondria of the amoeba to the plasma membrane of the Legionella containing vacuole [36-38]. Owing to the proteins of the Type IVB defect in organelle trafficking/intracellular multiplication (Dot/Icm) secretion system, that aid in the establishment and the preservation of the Legionella containing vacuole, Legionella are then able to proliferate in this protective rough endoplasmic reticulum-like compartment [38, 39]. Once nutrients within the Legionella containing vacuole become limiting, Legionella will kill the amoeba and escape, where after they either establish a new replicative niche within a new host or continue to survive as planktonic cells and/or within biofilms as sessile cells $[39,40]$. It has then been suggested that the growth of Legionella within amoeba hosts in the environment, is required to select or maintain virulent strains of Legionella able to cause Legionnaires' disease [18, 39].

Numerous Legionella spp. (e.g. L. pneumophila and L. longbeachea, amongst others) have been known to cause the acute potentially fatal form of pneumonia as part of a multisystem disease known as Legionnaires' disease (also referred to as Legionellosis or Legion Fever) [41] or a milder form of pulmonary infection known as Pontiac fever, which is a flu like illness [42]. Since the outbreak of Legionnaires' disease has previously been linked to roof-harvested rainwater systems $[8,43]$ and hot water distribution systems [44], the aim of the current study was to isolate and identify the primary Legionella spp. contaminating a harvested rainwater and a solar pasteurization 
(SOPAS) system (used for the treatment of roof-harvested rainwater) and to identify possible vectors including Acanthamoeba spp., V. vermiformis and $N$. fowleri, enabling their resistance and persistence. The viability of the FLA's as well as Legionella spp. at temperatures greater than $68^{\circ} \mathrm{C}$ was also determined using EMA-qPCR. The enumeration of heterotrophic bacteria was included as previous studies have suggested that a correlation may exist between the heterotrophic plate count and Legionella, as Legionella multiply in biofilms as a survival strategy in the environment [45-47]. Additionally, the heterotrophic plate count was utilized to monitor the change in the number of viable heterotrophic bacteria before and after pasteurization [48]. Unpasteurized and pasteurized rainwater samples treated at temperatures of $45{ }^{\circ} \mathrm{C}, 65^{\circ} \mathrm{C}, 68{ }^{\circ} \mathrm{C}, 74{ }^{\circ} \mathrm{C}, 84{ }^{\circ} \mathrm{C}$ and $93^{\circ} \mathrm{C}$, were collected for the enumeration of the heterotrophic plate count and the isolation of Legionella spp. However, as previous research has indicated that the indicator counts are reduced to below the detection limit at temperatures greater than $70{ }^{\circ} \mathrm{C}[13,17]$, the samples collected at temperatures of $68{ }^{\circ} \mathrm{C}, 74{ }^{\circ} \mathrm{C}, 84{ }^{\circ} \mathrm{C}$ and $93{ }^{\circ} \mathrm{C}$ only were utilized for the EMA-qPCR experiments.

\section{Methods}

\section{Sample site and collection}

The Apollo ${ }^{\text {Tx }}$ solar pasteurization system previously described by Dobrowsky et al. [13] was utilized for the treatment of harvested rainwater stored in a polyethylene rainwater harvesting (RWH) tank (2000 l). The RWH tank and pasteurization system were installed at the Welgevallen experimental farm $\left(33^{\circ} 56^{\prime} 36.19^{\prime \prime} \mathrm{S}, 18^{\circ} 52^{\prime} 6.08^{\prime \prime}\right.$ E), Stellenbosch University, Western Cape, South Africa, during July 2013. Samples (5 l) pasteurized at $45^{\circ}$ C, $65{ }^{\circ} \mathrm{C}, 68{ }^{\circ} \mathrm{C}, 74{ }^{\circ} \mathrm{C}, 84{ }^{\circ} \mathrm{C}$ and $93{ }^{\circ} \mathrm{C}$ were collected from the Apollo ${ }^{\text {Ta }}$ solar pasteurization system during September and October 2015, with six corresponding unpasteurized tank water samples (5 l) collected from the connecting RWH tank. The $\mathrm{pH}$ and temperature of the tank water samples were recorded at the sampling site, using a using a handheld $\mathrm{pH} 55 \mathrm{pH} /$ temperature meter (Martini Instruments, North Carolina, USA) and an alcohol thermometer, respectively.

Ambient temperature for the Stellenbosch area during 2015 were obtained from the South African Weather Services (Pretoria, South Africa), while global horizontal irradiance $\left(\mathrm{GHI} ; \mathrm{W} / \mathrm{m}^{2}\right)$ data were obtained from Stellenbosch Weather Services, Engineering Faculty, Stellenbosch University (http://weather.sun.ac.za/).

\section{Enumeration of the heterotrophic plate count}

For the enumeration of the heterotrophic plate count, a serial dilution (1:10) was prepared for each unpasteurized and pasteurized tank water sample, respectively, and $100 \mu \mathrm{l}$ of each undiluted and diluted $\left(10^{-1}-10^{-2}\right)$ sample was spread plated onto Reasoner's 2A agar (R2A agar; Difco Laboratories, Detroit, Michigan, USA), with the plates incubated at $37^{\circ} \mathrm{C}$ for up to 4 days in accordance with Standard Methods 9215 C, American Public Health Association [49].

\section{Isolation of Legionella spp. from pasteurized and unpasteurized tank water samples}

Legionella spp. were recovered from the pasteurized $\left(45{ }^{\circ} \mathrm{C}, 65{ }^{\circ} \mathrm{C}, 68{ }^{\circ} \mathrm{C}, 74{ }^{\circ} \mathrm{C}, 84{ }^{\circ} \mathrm{C}\right.$ and $\left.93{ }^{\circ} \mathrm{C}\right)$ and unpasteurized tank water samples according to the procedure outlined by the Centers for Disease Control and Prevention [50]. Briefly, $500 \mathrm{ml}$ of each sample collected from the domestic rainwater harvesting tank and from the pasteurization system, respectively, was filtered through a sterile GN-6 Metricel $^{\bullet}$ S-Pack Membrane Disc Filter (Pall Life Sciences, Michigan, USA) with a pore size of $0.45 \mu \mathrm{m}$ and a diameter of $47 \mathrm{~mm}$. The filtration flow rate was approximately $\geq 65 \mathrm{ml} / \mathrm{min} / \mathrm{cm}^{2}$ at $0.7 \mathrm{bar}(70 \mathrm{kPa})$. The filters were then aseptically removed from the filtration system and were placed into sterile $50 \mathrm{ml}$ centrifuge tubes containing sterile water $(5 \mathrm{ml})$. If more than one filter was required, additional filters were added to the same sample tube. The centrifuge tubes were then vortexed to detach the cells from the filters. As Legionella detection and isolation may be hampered by the growth of non-Legionella background flora [51], the selective detection for the unpasteurized tank water samples was increased by preincubating the cell suspension at $50{ }^{\circ} \mathrm{C}$ for $30 \mathrm{~min}$ before cultivation [50]. Thereafter, $100 \mu \mathrm{l}$ of the cell suspension was spread plated onto buffered charcoal yeast extract (BCYE) agar containing ACES [ $N$-(2-acetamido)-2-aminoethanesulfonic acid] buffer/potassium hydroxide $(1.0 \mathrm{~g} / \mathrm{l})$, ferric pyrophosphate $(0.025 \mathrm{~g} / \mathrm{l})$, alpha-ketoglutarate $(0.10 \mathrm{~g} / \mathrm{l})$ and $L$-cysteine HCL $(0.04 \mathrm{~g} / \mathrm{l})$ (Oxoid, Hampshire, England), BCYE agar supplemented with glycine, vancomycin, polymyxin B and cycloheximide (GVPC) and charcoal yeast extract (CYE) agar base without supplements (Oxoid, Hampshire, England).

All plates were then incubated at $35^{\circ} \mathrm{C}$ for approximately 10 days. Colonies exhibiting a convex and round with entire morphology that appeared on the BCYE and GVBC media and not on the CYE medium were selected for further analysis. To confirm the presence of presumptive Legionella spp., colonies were streaked onto BCYE agar and Nutrient Agar (NA; Merck, Gauteng, South Africa) as a preliminary identification strategy. Colonies that grew only on BCYE agar and not NA were presumptively classified as Legionella spp. and were utilized for further analysis.

\section{Total genomic DNA extractions from presumptive Legionella isolates}

Total genomic DNA (gDNA) extractions were performed for presumptive Legionella spp. isolated from the tank 
water samples present on the BCYE and GVBC media and not on the CYE media. Before the extraction of DNA, presumptive Legionella colonies were inoculated into buffered yeast extract (BYE) broth supplemented with ACES buffer/potassium hydroxide $(1.0 \mathrm{~g} / \mathrm{l})$, ferric pyrophosphate $(0.025 \mathrm{~g} / \mathrm{l})$, alpha-ketoglutarate $(0.10 \mathrm{~g} / \mathrm{l})$ and $L$-cysteine HCL $(0.04 \mathrm{~g} / \mathrm{l})$ according to Edelstein \& Edelstein [52]. Presumptive Legionella cultures were then incubated at $\pm 35{ }^{\circ} \mathrm{C}$ for 4 days. Total gDNA was extracted from the cultures using the boiling method previously described by Ndlovu et al. [53].

\section{Ethidium monoazide (EMA) treatment and total gDNA extractions from pasteurized and unpasteurized tank water samples}

For the detection and quantification of Legionella spp., Acanthamoeba spp., $N$. fowleri and $V$. vermiformis total gDNA was extracted from pasteurized $\left(68^{\circ} \mathrm{C}, 74{ }^{\circ} \mathrm{C}, 84{ }^{\circ} \mathrm{C}\right.$, $93{ }^{\circ} \mathrm{C}$ ) and the corresponding unpasteurized tank water samples. For this, $1 \mathrm{l}$ of each sample was first subjected to flocculation as previously described by Dobrowsky et al. [54]. Briefly, $2 \mathrm{ml}$ of $\mathrm{CaCl}_{2}(1 \mathrm{M})$ and $2 \mathrm{ml}$ of $\mathrm{Na}_{2} \mathrm{HPO}_{4}$ $(1 \mathrm{M})$ were added to each sample before the samples were stirred (room temperature) for $5 \mathrm{~min}$. The samples were then concentrated by filtration as outlined above. For the detachment of cells from the filters, the filters were transferred to $4 \mathrm{ml}$ citrate buffer $(0.3 \mathrm{M}, \mathrm{pH} 3.5)$ and were vortexed. The filters were subsequently removed and the $4 \mathrm{ml}$ suspension was centrifuged at $16000 \times g$ for $10 \mathrm{~min}$. After the removal of the supernatant the pellet was re-suspended in $1 \mathrm{ml}$ sterile MilliQ water before EMA treatment.

Ethidium monoazide $(2.5 \mu \mathrm{g} / \mathrm{ml})$ was added to the $1 \mathrm{ml}$ of concentrated sample according to Delgado-Viscogliosi et al. [55] and Chang et al. [56]. The suspension was then vortexed vigorously and placed on ice for $10 \mathrm{~min}$ in the dark. To cross link the EMA to the naked DNA, the samples were kept horizontal on ice and were exposed to a $500 \mathrm{~W}$ halogen light for $15 \mathrm{~min}$ at a distance of $20 \mathrm{~cm}$. Following centrifugation $(16000 \times g, 5 \mathrm{~min})$, the supernatant was removed and the pellet was washed with $1 \mathrm{~mL} \mathrm{NaCl}$ $(0.85 \%)$. The sample was centrifuged $(16000 \times g, 5 \mathrm{~min})$ and the pellet was re-suspended in $700 \mu \mathrm{l}$ lysis buffer. The extraction of total gDNA was then performed using the Soil Microbe DNA MiniPrep ${ }^{\text {tw }}$ Kit (Zymo Research, Irvine, USA) according to manufacturer's instructions.

\section{Conventional PCR assays for the identification of Legionella isolates}

For the identification of the presumptive Legionella isolates, DNA was extracted from each isolate as outlined above. The primer set LEG 225/LEG 858 was then utilized to amplify $634 \mathrm{bp}$ of the $16 \mathrm{~S}$ rRNA sequence as previously described by Miyamoto et al. [57] (Table 1). The PCR mix consisted of $10 \mu \mathrm{l}$ of $5 \times$ Green GoTaq ${ }^{\circ}$ Flexi Buffer (1×; Promega, Madison, USA), $4 \mu \mathrm{MgCl}_{2}$ (2.0 mM; Promega), $0.5 \mu \mathrm{l}$ of each dNTP $(0.1 \mathrm{mM}$; Thermo Fischer Scientific, Waltham, USA), $2 \mu \mathrm{l}$ of each PCR primer (LEG 225 and LEG 858; $0.4 \mu \mathrm{M}), 0.3 \mu \mathrm{l}$ of GoTaq ${ }^{\circ}$ Flexi DNA Polymerase (1.5U; Promega) and $2 \mu \mathrm{l}$ of template DNA. All conventional PCR mixtures consisted of a final volume of $50 \mu \mathrm{l}$. The PCR cycling parameters were as follows: initial denaturation at $95^{\circ} \mathrm{C}(1.5 \mathrm{~min})$ followed by 30 cycles of denaturation at $94{ }^{\circ} \mathrm{C}(10 \mathrm{~s})$, annealing at $64{ }^{\circ} \mathrm{C}(1 \mathrm{~min})$ and elongation at $74{ }^{\circ} \mathrm{C}(1 \mathrm{~min})$. A final extension was included at $72{ }^{\circ} \mathrm{C}(10 \mathrm{~min})$.

\section{Quantification of viable Legionella spp., Acanthamoeba spp., $N$. fowleri and $V$. vermiformis in pasteurized and unpasteurized tank water samples}

For the quantification of viable Legionella spp., Acanthamoeba spp., N. fowleri and V. vermiformis in pasteurized

Table 1 Primers and amplification conditions utilized in the current study for the identification and quantification of Legionella spp., Acanthamoeba spp., Naegleria fowleri and Vermamoeba (Hartmannella) vermiformis in pasteurized and unpasteurized tank water samples

\begin{tabular}{|c|c|c|c|c|c|}
\hline Organism & Primer name & Primer sequence $\left(5^{\prime}-3^{\prime}\right)$ & $\begin{array}{l}\text { Gene } \\
\text { (size, bp) }\end{array}$ & Amplification conditions & Reference \\
\hline \multirow{2}{*}{$\begin{array}{l}\text { Legionella spp. } \\
\text { (Identification) }\end{array}$} & LEG 225 & AAGATTAGCCTGCGTCCGAT & \multirow{2}{*}{$\begin{array}{l}16 \mathrm{~S} \text { rRNA } \\
(634)\end{array}$} & \multirow{2}{*}{$\begin{array}{l}95^{\circ} \mathrm{C}(1.5 \mathrm{~min}) \text { followed by } 30 \text { cycles } \\
\text { of } 94{ }^{\circ} \mathrm{C}(10 \mathrm{~s}), 64^{\circ} \mathrm{C}(1 \mathrm{~min}) \text { and } 74{ }^{\circ} \mathrm{C} \\
(1 \mathrm{~min}) \text {. Final extension: } 72^{\circ} \mathrm{C}(10 \mathrm{~min}) .\end{array}$} & \multirow{2}{*}{$\begin{array}{l}\text { Miyamoto } \\
\text { et al. [57] }\end{array}$} \\
\hline & LEG 858 & GTCAACTTATCGCGTTTGCT & & & \\
\hline \multirow[t]{2}{*}{ Legionella spp. } & Leg $F$ & CTAATTGGCTGATTGTCTTGAC & \multirow{2}{*}{$\begin{array}{l}\text { 23S-5S rRNA } \\
(259)\end{array}$} & \multirow{2}{*}{$\begin{array}{l}95^{\circ} \mathrm{C}(1 \mathrm{~min}) \text { followed by } 45 \text { cycles of } \\
95^{\circ} \mathrm{C}(15 \mathrm{~s}), 60{ }^{\circ} \mathrm{C}(15 \mathrm{~s}) \text { and } 72{ }^{\circ} \mathrm{C}(11 \mathrm{~s})\end{array}$} & \multirow{2}{*}{$\begin{array}{l}\text { Herpers } \\
\text { et al. [58] }\end{array}$} \\
\hline & Leg $R$ & CAATCGGAGTTCTTCGTG & & & \\
\hline \multirow[t]{2}{*}{ Acanthamoeba spp. } & AcantF900 & CCCAGATCGTITACCGTGAA & \multirow{2}{*}{$\begin{array}{l}\text { 18S rDNA } \\
( \pm 180)\end{array}$} & \multirow{2}{*}{$\begin{array}{l}95^{\circ} \mathrm{C}(1 \mathrm{~min}) \text { followed by } 45 \mathrm{cycles} \text { of } \\
95^{\circ} \mathrm{C}(15 \mathrm{~s}), 60^{\circ} \mathrm{C}(1 \mathrm{~min}) \text { and } 72^{\circ} \mathrm{C}(40 \mathrm{~s})\end{array}$} & \multirow{2}{*}{$\begin{array}{l}\text { Qvarnstrom } \\
\text { et al. [59] }\end{array}$} \\
\hline & AcantR1100 & TAAATATTAATGCCCCCAACTATCC & & & \\
\hline \multirow[t]{2}{*}{ Naegleria fowleri } & NaegIF192 & GTGCTGAAACCTAGCTATTGTAACTCAGT & \multirow{2}{*}{$\begin{array}{l}\text { 18S rDNA } \\
(153)\end{array}$} & \multirow{2}{*}{$\begin{array}{l}95^{\circ} \mathrm{C}(1 \mathrm{~min}) \text { followed by } 45 \text { cycles of } \\
95^{\circ} \mathrm{C}(15 \mathrm{~s}), 64{ }^{\circ} \mathrm{C}(1 \mathrm{~min}) \text { and } 72^{\circ} \mathrm{C}(1 \mathrm{~min})\end{array}$} & \multirow{2}{*}{$\begin{array}{l}\text { Qvarnstrom } \\
\text { et al. [59] }\end{array}$} \\
\hline & NaegIR344 & CACTAGAAAAAGCAAACCTGAAAGG & & & \\
\hline \multirow{2}{*}{$\begin{array}{l}\text { Vermamoeba } \\
\text { (Hartmannella) } \\
\text { vermiformis }\end{array}$} & $\mathrm{Hv} 1227 \mathrm{~F}$ & TTACGAGGTCAGGACACTGT & \multirow{2}{*}{$\begin{array}{l}\text { 18S rRNA } \\
(502)\end{array}$} & \multirow{2}{*}{$\begin{array}{l}95^{\circ} \mathrm{C} \text { (3 min) followed by } 45 \text { cycles of } \\
95^{\circ} \mathrm{C}(20 \mathrm{~s}), 58^{\circ} \mathrm{C}(30 \mathrm{~s}) \text { and } 72{ }^{\circ} \mathrm{C}(40 \mathrm{~s})\end{array}$} & \multirow{2}{*}{$\begin{array}{l}\text { Kuiper } \\
\text { et al. [60] }\end{array}$} \\
\hline & Hv1728R & GACCATCCGGAGTTCTCG & & & \\
\hline
\end{tabular}


$\left(68{ }^{\circ} \mathrm{C}, 74{ }^{\circ} \mathrm{C}, 84{ }^{\circ} \mathrm{C}, 93{ }^{\circ} \mathrm{C}\right)$ and unpasteurized tank water samples, quantitative PCR (qPCR) was performed using a LightCycler ${ }^{\bullet} 96$ (Roche, Gauteng, South Africa) following EMA treatment. For all qPCR assays, to a final reaction volume of $20 \mu \mathrm{l}$, using the FastStart Essential DNA Green Master Mix (Roche Applied Science, Mannheim, Germany), the following were added: $10 \mu \mathrm{l}$ FastStart Essential DNA Green Master Mix (2×), $5 \mu \mathrm{l}$ template DNA, and $0.4 \mu \mathrm{l}$ of each primer $(0.2 \mu \mathrm{M})$.

For the quantification of Legionella spp. in pasteurized and unpasteurized tank water samples, the primers and qPCR parameters according to Herpers et al. [58] were utilized (Table 1). To generate a standard curve for the quantification of Legionella spp., the purified conventional PCR product obtained by amplifying the 256 bp product from L. pneumophila ATCC 33152 was utilized.

For the quantification of Acanthamoeba spp. in pasteurized and unpasteurized tank water samples, the primers and qPCR parameters as previously described by Qvarnstrom et al. [59] were utilized (Table 1). To generate the standard curve for the quantification of Acanthamoeba spp., the 180 bp PCR product amplified from gDNA of A. mauritaniensis ATCC 50677 was cloned into the pGEM T-easy vector system (Promega Corp.) according to the manufacturer's instructions. Once the plasmid had been sequenced, the plasmid containing the correct insert was used to generate the standard curve.

Additionally, for the quantification of N. fowleri in pasteurized and unpasteurized tank water samples, the primers and qPCR parameters as outlined by Qvarnstrom et al. [59] were utilized (Table 1). To generate the standard curve for the quantification of $N$. fowleri a purified $153 \mathrm{bp}$ PCR product obtained by screening a 11 tank water sample from a domestic rainwater harvesting tank located at Stellenbosch University (GPS coordinates: $33^{\circ}$ $\left.55^{\prime} 51.1^{\prime \prime S}, 18^{\circ} 51^{\prime} 56.7^{\prime \prime E}\right)$ using the NaeglF192/NaeglR344 primer set was cloned into the pGEM T-easy vector system (Promega Corp.) according to the manufacturer's instructions. Once the plasmid had been sequenced, the plasmid containing the correct insert was used to generate the standard curve for the quantification of $N$. fowleri.

For the quantification of $V$. vermiformis in pasteurized and unpasteurized tank water samples, the primers and qPCR parameters according to Kuiper et al. [60] were utilized (Table 1). To generate a standard curve for the quantification of $V$. vermiformis, the purified conventional PCR product (502 bp) obtained by screening a 11 tank water sample from a domestic rainwater harvesting tank located at Stellenbosch University (GPS coordinates: $33^{\circ} 55^{\prime} 51.1^{\prime \prime S}, 18^{\circ} 51^{\prime} 56.7^{\prime \prime E}$ ) using the Hv1227F/Hv1728R primer set was utilized.

The concentration of the purified PCR products (Legionella spp. and $V$. vermiformis) and plasmid DNA (Acanthamoeba spp. and $N$. fowleri) were quantified using the
NanoDrop ND-1000 (Nanodrop Technologies Inc., Wilmington, Delaware, USA) in triplicate at CAF. Serial 10-fold dilutions $\left(10^{9}\right.$ to $\left.10^{1}\right)$ of the sequenced conventional PCR products and plasmid DNA were prepared in order to generate the standard curves for each respective organism. A concentration of $1.00 \times 10^{9}$ gene copies $/ \mu \mathrm{l}$ was prepared for the dilution with the highest copy number and a concentration of $1.00 \times 10^{1}$ gene copies/ $\mu \mathrm{l}$ was prepared for the dilution with the lowest copy number. Standard curves generated by plotting quantitative cycle (Cq) values $v s$ the log concentrations of standard DNA as previously described by Chen and Chang [61], were then used to determine the number of gene copies of each of the organisms. Melt curve analysis was included for all SYBR green real-time PCR assays in order to verify specificity of the primer set by ramping the temperature from 65 to $97{ }^{\circ} \mathrm{C}$ at a rate of $0.2{ }^{\circ} \mathrm{C} / \mathrm{s}$ with continuous fluorescent signal acquisition at 5 readings $/{ }^{\circ} \mathrm{C}$.

\section{Sequencing of PCR amplicons}

The PCR amplicons of each presumptive Legionella isolate, the PCR products used as positive controls to generate the standard curves for each qPCR assay and representative products of each of the qPCR assays of each organism were then purified using the DNA Clean \& Concentrator ${ }^{\mathrm{rm}}-5 \mathrm{Kit}$ (Zymo Research) and were sent for sequencing at the CAF, Stellenbosch University. Chromatograms of each sequence were examined as outlined in Dobrowsky et al. [12] and all sequences were submitted as a query to BLAST for a sequence similarity search against the NCBI databases (https://blast.ncbi.nlm.nih.gov/Blast.cgi).

\section{Inter- and intra-assay reproducibility and the lower limit of detection}

To establish the inter-assay reproducibility of the qPCR assays optimized for each respective organism, the coefficient of variation $(\mathrm{CV})$ was determined using the concentrations of nine dilutions $\left(10^{9}\right.$ to $\left.10^{1}\right)$ of conventional PCR products and plasmid DNA that were quantified in duplicate during three separate qPCR experiments. In addition, the $\mathrm{CV}$ for intra- assay repeatability was calculated using the concentrations of nine dilutions $\left(10^{9}\right.$ to $\left.10^{1}\right)$ for each qPCR assay [62-65]. In order to eliminate any PCR inhibitors, samples resulting in end-point fluorescence (EPF) values of less than 3.15 were diluted $(10 \times)$ and the $\mathrm{qPCR}$ experiment was repeated for these samples. The minimum number of gene copies (highest dilution) that could be measured accurately within an assay was considered the lower limit of detection for each organism [63].

\section{Statistical analysis}

The data obtained from the microbial and physical analysis of the tank water samples collected, were assessed using the Statistical software package, Statistica ${ }^{\text {tx }}$ version 
13.0 (Statsoft Inc.). Before the data analysis, the ShapiroWilk test was used to test the normality of data sets. The gene copies of Legionella spp., Acanthamoeba spp., $V$. vermiformis and $N$. fowleri obtained for the pasteurized and unpasteurized tank water samples were assessed for nonparametric differences using the Mann-Whitney $U$ test. Thus, the temperature of the tank water samples, before and after pasteurization was used as a single, ordinal variable. Spearman's rank $(\rho)$ correlation tests were performed to establish correlations between different microbiological (the heterotrophic plate count, number of Legionella isolates, the gene copies of Legionella spp., Acanthamoeba spp., $V$. vermiformis and $N$. fowleri obtained before and after pasteurization) and physical parameters ( $\mathrm{pH}$ and temperature of tank water samples) as previously described by Wang et al. [66]. Significance was set at a $P$-value of $\leq 0.05$ for all statistical analyses performed.

\section{Results}

Physical parameters of pasteurized and unpasteurized tank water samples collected during the sampling period (September-October 2015)

Pasteurized $\left(45{ }^{\circ} \mathrm{C}, 65{ }^{\circ} \mathrm{C}, 68{ }^{\circ} \mathrm{C}, 74{ }^{\circ} \mathrm{C}, 84{ }^{\circ} \mathrm{C}\right.$ and $\left.93{ }^{\circ} \mathrm{C}\right)$ tank water samples were collected from the Apollo ${ }^{\text {tw }}$ solar pasteurization system with corresponding unpasteurized tank water samples collected from the RWH tank during September and October 2015. The average daily ambient temperature ranged from $15.7{ }^{\circ} \mathrm{C}$ (September 2015) to $18.5^{\circ} \mathrm{C}$ (October 2015). Additionally, as the Apollo ${ }^{\mathrm{Tm}}$ solar pasteurization system relies on radiation from the sun to heat the tank water, the average total GHI was recorded at $8288.9 \mathrm{~W} / \mathrm{m}^{2}$ during September 2015 and $11574.6 \mathrm{~W} / \mathrm{m}^{2}$ during October 2015. The temperature of the water samples collected from the RWH tank ranged from the lowest temperature of $18{ }^{\circ} \mathrm{C}(15.09 .2015)$ to the highest recorded temperature of $31{ }^{\circ} \mathrm{C}(27.10 .2015)$. An average $\mathrm{pH}$ of 8.0 (range: 7.9-8.1) was recorded for unpasteurized tank water samples which then increased to $\mathrm{pH} 8.3$ (range: 8.2-8.5) after pasteurization (Table 2).

\section{The heterotrophic plate count and culturing of Legionella spp}

For all unpasteurized tank water samples $(n=6)$, the heterotrophic plate count numbers ranged from $2.7 \times$ $10^{5} \mathrm{CFU} / \mathrm{ml}$ to $1.5 \times 10^{6} \mathrm{CFU} / \mathrm{ml}$ and were above the Department of Water Affairs and Forestry (DWAF) [14] guideline of $100 \mathrm{CFU} / \mathrm{ml}$ (Table 2). Additionally, the heterotrophic plate count were above the DWAF [14] guidelines following pasteurization at $45{ }^{\circ} \mathrm{C}(1.5 \times$ $\left.10^{5} \mathrm{CFU} / \mathrm{ml}\right)$ and $65{ }^{\circ} \mathrm{C}\left(4.7 \times 10^{2} \mathrm{CFU} / \mathrm{ml}\right)$, respectively (results not shown). However, after the pasteurization treatment for the temperatures ranging from 68 to $93{ }^{\circ} \mathrm{C}$, heterotrophic plate counts were reduced to below the detection limit $(<1 \mathrm{CFU} / \mathrm{ml})$ and were within the DWAF guidelines (Table 2).

\section{Conventional PCR for the identification of Legionella isolates}

Culture based methods were then utilized to isolate Legionella spp. from all pasteurized $(n=6)$ and unpasteurized $(n=6)$ tank water samples. While no Legionella spp. were isolated from pasteurized tank water samples $\left(45^{\circ} \mathrm{C}\right.$ to $93{ }^{\circ} \mathrm{C}$ ), Legionella spp. were isolated from all the unpasteurized tank water samples utilizing culturing methods (Table 2). A total of 82 Legionella isolates were obtained overall from all the unpasteurized samples and all the resulting DNA sequences of the Legionella isolates displayed similarities to sequences of Legionella spp. recorded on NCBI. Legionella longbeachae $(n=29$; GenBank accession no: FN650140.1, JN606078.1, NR_102800.1) was the species most frequently isolated from the unpasteurized tank water samples (results not

Table 2 Microbiological parameters and physical parameters determined for pasteurized and unpasteurized harvested rainwater samples

\begin{tabular}{|c|c|c|c|c|c|c|c|c|}
\hline \multirow[t]{2}{*}{ Date } & \multirow{2}{*}{$\begin{array}{l}\text { Unpasteurized } \\
\text { and pasteurized } \\
\text { sample temp. }\left({ }^{\circ} \mathrm{C}\right)\end{array}$} & \multirow[t]{2}{*}{$\mathrm{pH}$} & \multirow{2}{*}{$\begin{array}{l}\text { Heterotrophic } \\
\text { plate count } \\
(\mathrm{CFU} / \mathrm{ml})\end{array}$} & \multirow{2}{*}{$\begin{array}{l}\text { No. of Legionella } \\
\text { isolates obtained }\end{array}$} & \multicolumn{4}{|l|}{ Gene copies/ml } \\
\hline & & & & & Legionella spp. & Acanthamoeba spp. & $\begin{array}{l}\text { Vermamoeba } \\
\text { vermiformis }\end{array}$ & $\begin{array}{l}\text { Naegleria } \\
\text { fowleri }\end{array}$ \\
\hline \multirow[t]{2}{*}{22.10 .2015} & 24 & 8.4 & $1.5 \times 10^{6}$ & 9 & $6.5 \times 10^{4}$ & $9.8 \times 10^{4}$ & $5.7 \times 10^{6}$ & $1.6 \times 10^{5}$ \\
\hline & $68^{a}$ & 8.4 & $\mathrm{BDL}^{\mathrm{b}}$ & $\mathrm{BDL}^{\mathrm{b}}$ & $3.2 \times 10^{3}$ & $8.4 \times 10^{3}$ & $9.4 \times 10^{3}$ & $\operatorname{LLOD}^{d}$ \\
\hline \multirow[t]{2}{*}{22.10 .2015} & 25 & 8.1 & $1.0 \times 10^{6}$ & 2 & $4.5 \times 10^{4}$ & $8.3 \times 10^{4}$ & $3.9 \times 10^{4}$ & $6.4 \times 10^{4}$ \\
\hline & $74^{\mathrm{a}}$ & 8.5 & $\mathrm{BDL}^{\mathrm{b}}$ & $\mathrm{BDL}^{\mathrm{b}}$ & $9.2 \times 10^{3}$ & $5.2 \times 10^{3}$ & $\operatorname{LLOD}^{c}$ & $\operatorname{LLOD}^{d}$ \\
\hline \multirow[t]{2}{*}{ 19.10.2015 } & 21 & 8.3 & $6.8 \times 10^{5}$ & 1 & $5.7 \times 10^{6}$ & $1.3 \times 10^{5}$ & $1.4 \times 10^{5}$ & $9.2 \times 10^{4}$ \\
\hline & $84^{a}$ & 8.2 & $\mathrm{BDL}^{\mathrm{b}}$ & $\mathrm{BDL}^{\mathrm{b}}$ & $2.3 \times 10^{3}$ & $1.7 \times 10^{4}$ & $\operatorname{LLOD}^{c}$ & $\operatorname{LLOD}^{d}$ \\
\hline \multirow[t]{2}{*}{27.10 .2015} & 31 & 8.4 & $2.7 \times 10^{5}$ & 3 & $8.2 \times 10^{6}$ & $6.5 \times 10^{4}$ & $3.2 \times 10^{5}$ & $1.0 \times 10^{6}$ \\
\hline & $93^{\mathrm{a}}$ & 8.2 & $\mathrm{BDL}^{\mathrm{b}}$ & $\mathrm{BDL}^{\mathrm{b}}$ & $1.1 \times 10^{3}$ & $1.4 \times 10^{4}$ & $\operatorname{LLOD}^{c}$ & $\operatorname{LLOD}^{d}$ \\
\hline
\end{tabular}

\footnotetext{
Pasteurized rainwater sample

${ }^{\mathrm{b}} B D L$ below detection limit

${ }^{C}$ LLOD lower limit of detection: Vermamoeba vermiformis $(<5-8$ gene copies/ $\mu \mathrm{l})$

d LLOD lower limit of detection: Naegleria fowleri (< 12-17 gene copies/ $\mu$ l)
} 
shown), followed by Legionella norrlandica $(n=22)$ and Legionella rowbothamii $(n=3)$ (Fig. 1 ; accession numbers included), the remaining 28 isolates were undetermined Legionella species (results not shown) and BLAST analysis indicated the presence of uncultured Legionella spp. (GenBank accession no: HQ111985.1, HQ111937.1, GU185995.1) and Legionella spp. (GenBank accession no: JN380993.1, JN380988.1).

\section{Quantification of viable Legionella spp. present in pasteurized and unpasteurized tank water samples}

As the heterotrophic plate count was reduced to below the detection limit following pasteurization at $68{ }^{\circ} \mathrm{C}$ to $93{ }^{\circ} \mathrm{C}$, viable Legionella spp. were quantified in samples pasteurized at $68{ }^{\circ} \mathrm{C}, 74{ }^{\circ} \mathrm{C}, 84{ }^{\circ} \mathrm{C}, 93{ }^{\circ} \mathrm{C}$ and the four corresponding unpasteurized tank water samples (Table 2). For all unpasteurized tank water samples, the concentration of viable Legionella ranged from $4.5 \times 10^{4}$ gene copies $/ \mathrm{ml}\left(25{ }^{\circ} \mathrm{C}\right)$ to $8.2 \times 10^{6}$ gene copies $/ \mathrm{ml}\left(31{ }^{\circ} \mathrm{C}\right)$ (Table 2). After pasteurization treatment, the highest concentration of Legionella was detected at $74{ }^{\circ} \mathrm{C}(9.2 \times$ $10^{3}$ gene copies $/ \mathrm{ml}$ ) which then decreased to $1.1 \times 10^{3}$ gene copies/ml following pasteurization at $93{ }^{\circ} \mathrm{C}$ as indicated in Table 2. The number of Legionella gene copies then decreased by 1-log (87.2 \%) following pasteurization at $68{ }^{\circ} \mathrm{C}$ and $74{ }^{\circ} \mathrm{C}$, respectively. In contrast, a 3-log reduction (> $99.9 \%$ ) in Legionella gene copies was observed following pasteurization at $84{ }^{\circ} \mathrm{C}$, while a $4-\log (>99.9 \%)$ reduction in Legionella gene copies was observed following pasteurization at $93{ }^{\circ} \mathrm{C}$. Overall, the number of viable Legionella gene copies decreased significantly $(Z=3.034$; $P=0.0024)$ by an average of 2-logs $(93.6 \%)$ following pasteurization at $68-93{ }^{\circ} \mathrm{C}$. Representative $\mathrm{qPCR}$ products were sequenced and Legionella anisa (GenBank accession no: JN001853.1, Z24682.1) and Legionella monrovica (GenBank accession no: Z24729.1) were detected in representative pasteurized and unpasteurized tank water samples following BLAST analysis, respectively.

\section{Quantification PCR efficiency, reproducibility and lower limit of detection}

A linear range of quantification from $10^{9}$ to $10^{1}$ gene copies per $\mu$ of DNA extracts was observed for all standard curves produced for the quantification of Legionella spp., Acanthamoeba spp., $V$. vermiformis and $N$. fowleri, respectively. As indicated in Table 3, the qPCR assays had amplification efficiencies that ranged from 1.86 to 1.94 (Legionella spp.), 1.92 to 1.95 (Acanthamoeba spp.), 1.85

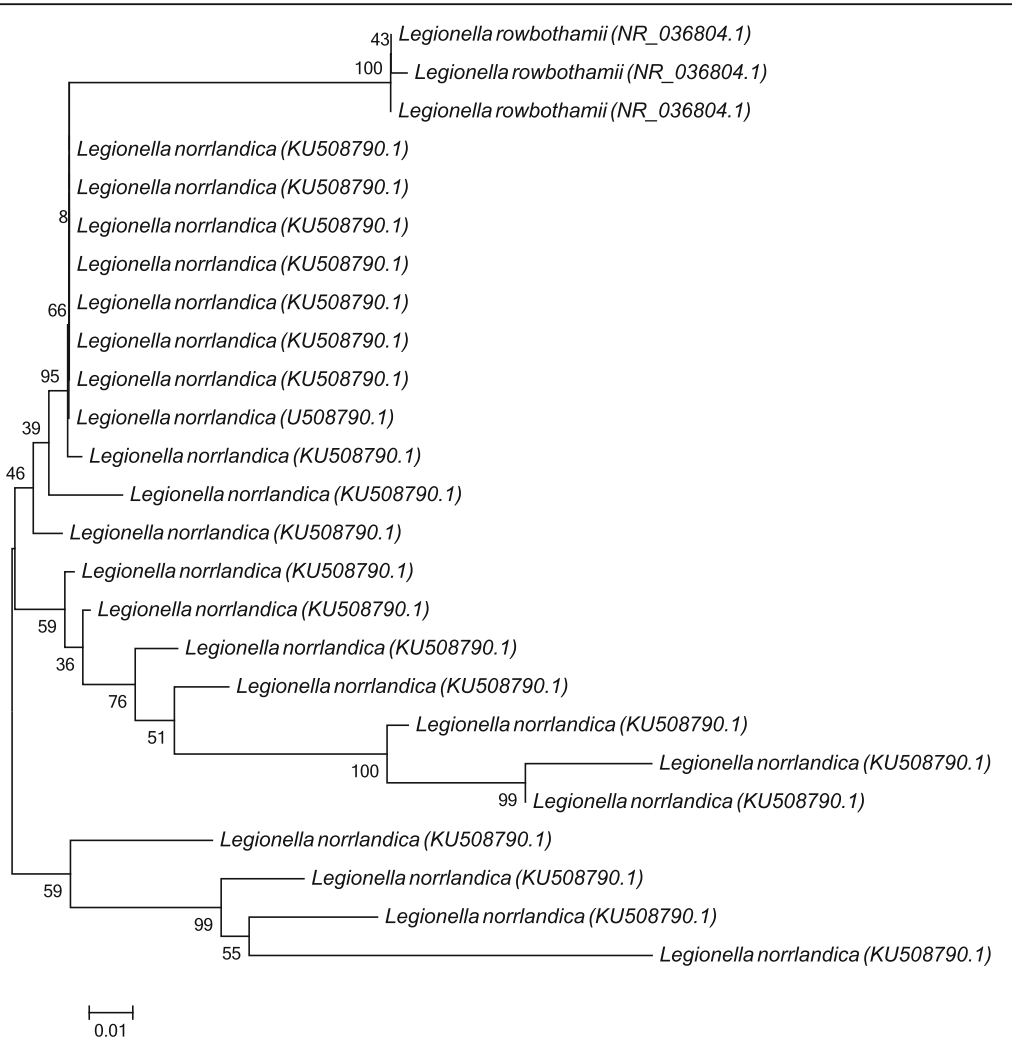

Fig. 1 Phylogenetic tree constructed from sequences of PCR products of Legionella norrlandica and Legionella rowbothamii isolates by means of the maximum composite likelihood function (evolutionary history) and neighbor-joining method using the program MEGA 5. The numbers found adjacent to the nodes represent the data (percentages) from 1,000 exploratory bootstrap trials. Bar: 0.002 changes per site. The L. norrlandica and L. rowbothamii isolates were obtained from unpasteurized tank water samples 
Table 3 The lower limit of detection (LLOD), amplification efficiency, correlation coefficient $\left(r^{2}\right)$, intra- and inter-assay reducibility within the range of $10^{9}$ to $10^{1}$ gene copies/ $\mu$ l of each qPCR assay

\begin{tabular}{|c|c|c|c|c|c|}
\hline \multirow[t]{2}{*}{ Organisms assayed } & \multirow{2}{*}{$\begin{array}{l}\text { LLOD (gene } \\
\text { copies/ } / \mu l)\end{array}$} & \multirow{2}{*}{$\begin{array}{l}\text { Amplification } \\
\text { efficiency (\%) }\end{array}$} & \multirow{2}{*}{$\begin{array}{l}\text { Correlation } \\
\text { coefficient }\left(r^{2}\right)\end{array}$} & \multicolumn{2}{|c|}{ Mean $\pm S D$ of $C V$} \\
\hline & & & & Intra-assay & Inter-assay \\
\hline Legionella spp. & $8-12$ & $1.86(93)-1.94(97)$ & $0.99-1.00$ & $0.160 \pm 0.257$ & $0.251 \pm 0.220$ \\
\hline Acanthamoeba spp. & $5-11$ & $1.92(96)-1.95$ (98) & $0.99-1.00$ & $0.142 \pm 0.283$ & $0.192 \pm 0.225$ \\
\hline Vermamoeba vermiformis & $5-8$ & $1.85(93)-1.89(95)$ & $0.98-1.00$ & $0.09 \pm 0.112$ & $0.129 \pm 0.092$ \\
\hline Naegleria fowleri & $12-17$ & $1.90(95)-2.04(102)$ & $0.99-1.00$ & $0.195 \pm 0.410$ & $0.348 \pm 0.251$ \\
\hline
\end{tabular}

Abbreviations: CV coefficient of variation, $L L O D$ lower limit of detection, SD standard deviation

to 1.89 ( $V$. vermiformis) and 1.90 to 2.04 ( $N$. fowleri). The optimum amplification efficiency is measured at 2.00 and corresponds to a doubling of copy number for every PCR cycle [67]. The correlation coefficient $\left(r^{2}\right)$ ranged from 0.99 to 1.00 for all qPCR assays performed for Legionella spp., Acanthamoeba spp. and N. fowleri and 0.98 to 1.00 for all qPCR assays performed $V$. vermiformis, respectively (Table 3). The qPCR lower limit of detection was recorded at 8-12 gene copies/ $\mu$ l for Legionella spp., 2-6 gene copies/ $\mu \mathrm{l}$ for Acanthamoeba spp., 5-8 gene copies/ $\mu \mathrm{l}$ for $V$. vermiformis and 12-17 gene copies/ $\mu \mathrm{l}$ for $N$. fowleri (Table 3). The qPCR assays demonstrated good reproducibility as the mean inter-and intra- assay coefficient of variation $(\mathrm{CV})$ values and standard deviations (SD) were less than 1 and $5 \%$ for all qPCR assays, respectively (Table 3 ).

\section{Quantification of FLAs present in pasteurized and unpasteurized tank water samples}

Following EMA treatment and DNA extractions, qPCR was performed for the quantification of viable Acanthamoeba spp., $V$. vermiformis and $N$. fowleri in samples pasteurized at $68{ }^{\circ} \mathrm{C}, 74{ }^{\circ} \mathrm{C}, 84{ }^{\circ} \mathrm{C}, 93{ }^{\circ} \mathrm{C}$ and the corresponding unpasteurized tank water samples, respectively (Table 2). As indicated in Table 2, gene copies of Acanthamoeba ranged from $6.5 \times 10^{4}$ gene copies $/ \mathrm{ml}\left(31{ }^{\circ} \mathrm{C}\right)$ to $1.3 \times 10^{5}$ gene copies $/ \mathrm{ml}\left(21{ }^{\circ} \mathrm{C}\right)$ for all unpasteurized tank water samples. After pasteurization treatment, the gene copies of Acanthamoeba spp. decreased and ranged from $5.2 \times 10^{3}$ gene copies $/ \mathrm{ml}\left(74^{\circ} \mathrm{C}\right)$ to $1.7 \times 10^{4}$ gene copies/ $\mathrm{ml}\left(84{ }^{\circ} \mathrm{C}\right)$ and $1.4 \times 10^{4}$ gene copies $/ \mathrm{ml}\left(93^{\circ} \mathrm{C}\right)$ (Table 2). Overall, the number of Acanthamoeba gene copies decreased significantly $(Z=-3.183 ; P=0.0015)$ by $1-\log$ $(87.3 \%)$ following pasteurization at $68-93{ }^{\circ} \mathrm{C}$. Acanthamoeba genotype T4 (GenBank accession no: KT892923.1), genotype T15 (GenBank accession no: KT892848.1) and Acanthamoeba lenticulata (GenBank accession no: KX018047.1) were detected in representative pasteurized and unpasteurized tank water samples, respectively.

For all unpasteurized tank water samples, the gene copies of viable $V$. vermiformis ranged from $3.9 \times 10^{4}$ gene copies $/ \mathrm{ml}\left(25^{\circ} \mathrm{C}\right)$ to $5.7 \times 10^{6}$ gene copies $/ \mathrm{ml}\left(24{ }^{\circ} \mathrm{C}\right)$ (Table 2). Following pasteurization, the gene copies of $V$. vermiformis decreased and ranged from $9.4 \times 10^{3}$ gene copies $/ \mathrm{mL}\left(68^{\circ} \mathrm{C}\right)$ to below the lower limit of detection $(<$ 5-8 gene copies/ $\mu \mathrm{l})$ for the remainder of the pasteurized samples $\left(74{ }^{\circ} \mathrm{C}\right.$ to $\left.93{ }^{\circ} \mathrm{C}\right)$. A $3-\log$ reduction $(99.9 \%)$ in $V$. vermiformis gene copies was observed following pasteurization at $68{ }^{\circ} \mathrm{C}$ while a 5 - $\log$ reduction $(>99.9 \%$ ) in gene copies of viable $V$. vermiformis was observed following pasteurization at $74{ }^{\circ} \mathrm{C}$ to $93{ }^{\circ} \mathrm{C}$, respectively. Overall, the number of gene copies of $V$. vermiformis (GenBank accession no: KT185625.1) decreased significantly $(Z=$ 3.067; $P=0.0021)$ by $5-\log (>99.9 \%)$ following pasteurization at $68-93^{\circ} \mathrm{C}$.

For all unpasteurized tank water samples, gene copies of viable $N$. fowleri ranged from $6.4 \times 10^{4}$ gene copies $/ \mathrm{ml}$ $\left(25{ }^{\circ} \mathrm{C}\right)$ to $1.0 \times 10^{6}$ gene copies/ml $\left(31{ }^{\circ} \mathrm{C}\right.$ ) (Table 2). Following pasteurization, the gene copies of $N$. fowleri decreased to below the lower limit of detection $(<12-17$ gene copies $/ \mu \mathrm{l})$ for all tank water samples pasteurized at $68{ }^{\circ} \mathrm{C}, 74{ }^{\circ} \mathrm{C}, 84{ }^{\circ} \mathrm{C}$ and $93{ }^{\circ} \mathrm{C}$, respectively (Table 2). A 5 - $\log$ reduction $(>99.9 \%)$ in N. fowleri gene copies was observed following pasteurization at $68{ }^{\circ} \mathrm{C}$ to $84{ }^{\circ} \mathrm{C}$, respectively, while a 6 -log reduction $(>99.9 \%)$ in gene copies of $N$. fowleri was observed following pasteurization at $93{ }^{\circ} \mathrm{C}$. Overall, the number of gene copies of viable $N$. fowleri (GenBank accession no: JQ271702.1, JQ271704.1) decreased significantly $(Z=3.308 ; P=0.001)$ by $5.2-\log$ (> $99.9 \%$ ) following pasteurization at $68-93{ }^{\circ} \mathrm{C}$.

\section{Associations of microbiological parameters and abiotic factors}

As indicated in Table 4, Spearman's ( $\rho$ ) correlations were noted between parameters measured throughout the study. For example, positive correlations were observed between the heterotrophic plate count and the number of Legionella isolates obtained $(\rho=0.779, P=0.0028)$ and the gene copies of Legionella spp. $(\rho=0.710, P=0.048)$, Acanthamoeba spp. $(\rho=0.862, P=0.006), V$. vermiformis $(\rho=$ $0.858, P=0.006)$ and $N$. fowleri $(\rho=0.810, P=0.015)$, respectively. Additionally, significant positive correlations were observed between the number of Legionella isolates obtained $v s$ the gene copies of Legionella spp. $(\rho=0.812$, $P=0.0014)$, Acanthamoeba spp. $(\rho=0.761, P=0.028)$, 
Table 4 Spearman rank order correlation coefficients $(\rho)$ of parameters investigated in this study

\begin{tabular}{lllllll}
\hline Parameter & Temperature $\left({ }^{\circ} \mathrm{C}\right)$ & $\mathrm{pH}$ & $\mathrm{HPC} / \mathrm{ml}$ & $\begin{array}{l}\text { No. of isolates } \\
\text { (Culture) }\end{array}$ & $\begin{array}{c}\text { Legionella spp. } \\
\text { Acanthamoeba spp. }\end{array} \begin{array}{c}\text { Vermamoeba } \\
\text { vermiformis }\end{array}$ \\
\hline Temperature $\left({ }^{\circ} \mathrm{C}\right)$ & - & & & & \\
$\mathrm{pH}$ & 0.367 & - & & & \\
$\mathrm{HPC} / \mathrm{ml}$ & $-0.847^{* *}$ & -0.246 & - & & \\
No. of isolates (Culture) & $-0.885^{* *}$ & -0.374 & $0.779^{* *}$ & - & - & - \\
Legionella spp. & $-0.833^{* *}$ & 0.306 & $0.710^{*}$ & $0.812^{*}$ & 0.643 & $0.756^{*}$ \\
Acanthamoeba spp. & $-0.809^{*}$ & -0.356 & $0.862^{* *}$ & $0.761^{*}$ & $0.854^{* *}$ & $0.761^{*}$ \\
Vermamoeba vermiformis & $-0.854^{* *}$ & 0.176 & $0.858^{* *}$ & $0.936^{* *}$ & $0.913^{* *}$ & $0.936^{* *}$ \\
Naegleria fowleri & $-0.761^{* *}$ & 0.118 & $0.810^{*}$ & $0.946^{* *}$ & &
\end{tabular}

${ }^{*} P<0.05,{ }^{*} P<0.01$

$V$. vermiformis $(\rho=0.936, P=0.001)$ and $N$. fowleri $(\rho=$ $0.946, P=0.0004)$, respectively. The number of Legionella spp. gene copies/ml were also positively correlated to the gene copies of the amoeba detected including $V$. vermiformis $(\rho=0.854, P=0.001), N$. fowleri $(\rho=0.913, P=0.002)$ and Acanthamoeba spp. $(\rho=0.643, P=0.085)$. Moderate to high correlations were then detected between the number of Acanthamoeba spp. gene copies vs the number of $V$. vermiformis $(\rho=0.756, P=0.03)$ and $N$. fowleri gene copies $(\rho=0.845, P=0.028)$, respectively. A high correlation was also established between the gene copies of $V$. vermiformis and of $N$. fowleri $(\rho=0.936, P=0.001)$.

\section{Discussion}

The heterotrophic plate count for all unpasteurized and tank water samples pasteurized at $45{ }^{\circ} \mathrm{C}$ and $65{ }^{\circ} \mathrm{C}$ were above the DWAF guideline for drinking water, with the heterotrophic plate count reduced to below the detection limit $(<1 \mathrm{CFU} / \mathrm{ml})$ following pasteurization at $68{ }^{\circ} \mathrm{C}$ to $93{ }^{\circ} \mathrm{C}$. The heterotrophic plate count represents only the culturable portion of the general bacterial community that are present in a water source and results indicated that pasteurization treatment at temperatures above $68{ }^{\circ} \mathrm{C}$ are effective as heterotrophic plate count counts in the treated samples corresponded to drinking water guidelines [14]. Previously, Sommer et al. [68] indicated that faecal coliforms were inactivated in river water at temperatures above $70{ }^{\circ} \mathrm{C}$ utilizing solar pasteurization. Moreover, Dobrowsky et al. [13] indicated that a closed-coupled solar pasteurization system operating at temperatures above $72{ }^{\circ} \mathrm{C}$ reduced the level of the heterotrophic plate count, E. coli and total coliforms to below the detection limit in harvested rainwater. In the current study a positive correlation between the heterotrophic plate count and the number of culturable Legionella present and the gene copies of viable Legionella spp. was also established. These results are in agreement with a study conducted by SerranoSuárez et al. [69], where Legionella spp. were isolated when the corresponding heterotrophic plate count concentrations were above $1 \times 10^{5} \mathrm{CFU} / 100 \mathrm{ml}$, indicating that the frequency at which Legionella spp. are isolated may depend on the presence of culturable heterotrophic bacteria. Additionally, positive correlations were established between the heterotrophic plate count and the number of gene copies of viable Acanthamoeba spp., $V$. vermiformis and $N$. fowleri. This is expected as these FLAs are heterotrophs and known grazes of bacteria and the heterotrophic plate count represents the general bacterial microbiota $[66,69,70]$. Furthermore, while results indicated that the $\mathrm{pH}$ of the unpasteurized and pasteurized tank water samples did not significantly influence the microbiological quality, an increase in temperature of the pasteurized harvested rainwater significantly reduced the heterotrophic plate count, the number of Legionella isolates obtained, and the gene copies of viable Legionella spp., Acanthamoeba spp., $V$. vermiformis and $N$. fowleri detected, respectively.

Legionella spp. were also isolated using culture based techniques and during the current study, the majority of the Legionella isolates were obtained from unpasteurized tank water samples at temperatures of $18{ }^{\circ} \mathrm{C}(52$ Legionella isolates) and $19{ }^{\circ} \mathrm{C}$ (15 Legionella isolates), respectively. Molecular analysis of the Legionella isolates obtained then indicated that L. longbeachae was the dominant Legionella spp. isolated from the unpasteurized tank water samples. While L. longbeachae is generally isolated from soil, including potting soil [71], this microorganism has previously been isolated from water samples collected from hospital reticulation systems and cooling towers and is able to proliferate in Acanthamoeba polyphaga [72-74]. In addition, while L. pneumophila serotype 1 is responsible for most of the human reported infections, 17 additional species have also been associated with disease and these include $L$. longbeachae, L. micdadei, L. anisa and L. bozemanii [75]. BLAST analysis also revealed that $L$. norrlandica was of the dominant Legionella spp. isolated from unpasteurized tank water samples. This Legionella spp. harbours the majority of the L. pneumophila virulence factors and has only 
recently been described, where Rizzardi et al. [76] isolated a novel Legionella genus from the biopurification systems of wood processing plants. Moreover, the study group revealed that $L$. norrlandica could establish a replicative vacuole in A. castellanii. Three isolates were also identified as Legionella rowbothamii. Adeleke et al. [77] reported on the characterization of a novel Legionella spp., namely $L$. rowbothamii, and to date no studies have reported on the isolation of $L$. rowbothamii from environmental samples. Moreover, no studies have indicated whether $L$. rowbothamii proliferates in protozoa. As $L$. rowbothamii was isolated during the current study, future research should thus elucidate whether $L$. rowbothamii is able to colonize and proliferate in amoeba species.

Although Legionella spp. were isolated from the unpasteurized tank water samples, no Legionella spp. were detected using the culture based methods in the pasteurized tank water samples $\left(45{ }^{\circ} \mathrm{C}\right.$ to $\left.93{ }^{\circ} \mathrm{C}\right)$. Numerous studies have indicated that temperatures below $50{ }^{\circ} \mathrm{C}$ are not sufficient to eradicate Legionella spp. from water distribution systems [13, 17, 46, 69] and it is therefore unexpected that Legionella spp. were not isolated from particularly the $45{ }^{\circ} \mathrm{C}$ pasteurized tank water sample. However, in agreement with previous studies that have focused on the thermal inactivation of Legionella spp., the culturability of Legionella from the pasteurized tank water samples may have been affected by the heat treatment and by the nutrient shock of going from a nutrient poor environment such as rainwater, onto the nutrient rich environment provided by the media, as this induces Legionella cells to enter a viable but noncultivable (VBNC) state $[78,79]$.

EMA-qPCR assays were then performed for all unpasteurized and tank water samples pasteurized at $68{ }^{\circ} \mathrm{C}, 74{ }^{\circ} \mathrm{C}, 84{ }^{\circ} \mathrm{C}$ and $93{ }^{\circ} \mathrm{C}$ to determine whether $\mathrm{Le}$ gionella and the FLA's were viable. Although viable $V$. vermiformis was detected in all the unpasteurized tank water samples, results indicated that solar pasteurization at $74-93{ }^{\circ} \mathrm{C}$ was effective in reducing the gene copies of $V$. vermiformis to below the lower limit of detection $(<5-$ 8 gene copies/ $\mu \mathrm{l})$. Additionally, $N$. fowleri were not detected in any of the pasteurized tank water samples and results of the current study thus indicate that the thermal treatment of tank water at $68-93{ }^{\circ} \mathrm{C}$ is sufficient for the removal of $N$. fowleri as the gene copies of viable $N$. fowleri were reduced to below the lower limit of detection $(<12-17$ gene copies/ $\mu \mathrm{l})$ for all pasteurized tank water samples. Although discrepancies, such as the presence of multicellular communities, may arise when analysing environmental samples, Fouque et al. [31] indicated that $V$. vermiformis cysts were completely inactivated at $70{ }^{\circ} \mathrm{C}$, which is in agreement with the current study, where $V$. vermiformis was more sensitive to heat treatment than Acanthamoeba spp. Additionally, previous studies have indicated that Naegleria spp. are considered more sensitive to heat treatments compared to thermotolerant Acanthamoeba and $V$. vermiformis [24, 80, 81]. Results obtained in the current study do however, indicate that rainwater harvesting tanks are vulnerable to $N$. fowleri and $V$. vermiformis colonization and amoeba, including $N$. fowleri and $V$. vermiformis, should be included in the surveillance of pathogens in drinking water distribution systems [82].

Viable Legionella spp. and Acanthamoeba spp. were then detected in all the pasteurized and unpasteurized tank water samples. It has been well established that Legionellae are facultative intracellular parasites of amoeba including, Acanthamoeba spp., Naegleria spp. and V. vermiformis [83]. Although significant positive correlations were observed between the number of Legionella gene copies and the gene copies of $V$. vermiformis and $N$. fowleri, it is hypothesized that Legionella spp. may primarily be associating with Acanthamoeba spp. during thermal treatment as viable Legionella spp. and Acanthamoeba spp. persisted in all pasteurized $\left(68{ }^{\circ} \mathrm{C}\right.$ to $\left.93{ }^{\circ} \mathrm{C}\right)$ and unpasteurized tank water samples. This is not surprising, as previous studies have detected Legionella at high pasteurization temperatures $\left(>90{ }^{\circ} \mathrm{C}\right)$ in solar pasteurization systems using molecular based techniques, including EMA-qPCR [13, 17]. Although this has not been demonstrated for all Legionella spp., L. pneumophila has been known to survive and proliferate on the debris of dead microbial cells such as heat-killed Pseudomonas putida, E. coli, Bacillus subtilis, Lactobacillus plantarum, A. castellanii and Saccharomyces boulardii [84]. Moreover, Acanthamoeba spp. are able to graze on heat killed bacteria including E. coli and Klebsiella spp. [70]. In agreement with Thomas et al. [81], it is thus hypothesized that the solar pasteurization system may be indirectly providing favourable conditions for Legionella and Acanthamoeba spp. and these organisms may thus be surviving on the dissolved organic constituents, available through the decay of the microorganisms at high pasteurization temperatures. However, while the presence of dissolved organic constituents may allow for the survival of Legionella spp., it is hypothesized that Acanthamoeba cysts may be harbouring Legionella and allow the Legionella spp. to proliferate and grow in harvested rainwater and during the treatment process. This is in agreement with Storey et al. [85] who indicated that Acanthamoebae cysts remained viable after heat treatment at $80{ }^{\circ} \mathrm{C}$ for $10 \mathrm{~min}$. It is further hypothesized that during the DNA extraction process the cysts may be lysed and Legionella are released and detected using molecular methods including EMA-qPCR. Additionally, the qPCR assays utilized in the current study indicated high reproducibility as the mean inter-assay $\mathrm{CV}$ values and $\mathrm{SD}$ were less than 5 and $1 \%$, respectively, which were comparable to CV and SD values obtained by Ahmed et al. [65]. 
The current study therefore highlights the value of EMAqPCR for the detection of viable Legionella and their protozoan hosts as opposed to culture based techniques that may yield false negative results [82].

\section{Conclusions}

Although incidences of Legionnaires' disease are well documented for regions including Europe, the USA, New Zealand and Australia, limited information is available on the environmental distribution of Legionella spp. as well as incidences of Legionnaires' disease in developing countries such as South Africa [83, 86-88]. The surveillance of Legionella in water distribution systems is thus vital as Legionella have been described as "new or emerging pathogens in drinking water" [89]. The current study demonstrated that culture-based methods for the detection of Legionella are less sensitive and with the use of EMA-qPCR, viable Legionella spp., Acanthamoeba spp., $V$. vermiformis and $N$. fowleri were detected in untreated tank water samples, while viable Legionella spp. $\left(93{ }^{\circ} \mathrm{C}\right)$, Acanthamoeba spp. $\left(93{ }^{\circ} \mathrm{C}\right)$ and $V$. vermiformis $\left(68{ }^{\circ} \mathrm{C}\right)$ were detected after pasteurization.

Additionally, insight into the presence and persistence of Legionella spp., and amoeba including Acanthamoeba, $V$. vermiformis and $N$. fowleri in a representative rainwater harvesting tank and a solar pasteurization treatment system was provided. The occurrence of these pathogens in harvested rainwater is of particular concern as they are frequently detected in water distribution systems and residential plumbing [45]. For example, $N$. fowleri is the causative agent of the disease, primary amoebic meningoencephalitis (PAM) and although PAM infections are rare, the mortality rate is extremely high [90].

The presence of viable Legionella spp. and Acanthamoeba spp. highlights the need for further investigation as solar pasteurization may be insufficient for the long-term control of pathogenic Acanthamoeba and Acanthamoebaebound Legionellae in harvested rainwater.

\section{Abbreviations}

ACES: N-(2-acetamido)-2-aminoethanesulfonic acid; BCYE: Buffered charcoal yeast extract; BLAST: Basic local alignment search tool; BYE: Buffered yeast extract; CAF: Central analytical facility; CV: Coefficient of variation; CYE: Charcoal yeast extract; Dot/lcm: Defect in organelle trafficking/intracellular multiplication; DWAF: Department of Water Affairs and Forestry; EMA: Ethidium monoazide; EMA-qPCR: Ethidium monoazide quantitative polymerase chain reaction; EPF: End-point fluorescence; FLA: Free-living amoeba; gDNA: Genomic DNA; GHI: Global horizontal irradiance; GVPC: Glycine, vancomycin, polymyxin B and cycloheximide; NA: Nutrient agar; NCBI: National centre for biotechnology information; qPCR: Quantitative PCR; R2A: Reasoner's 2A agar; RWH: Rainwater harvesting; SD: Standard deviation; VBNC: Viable but non-culturable

\section{Acknowledgements}

The authors would like to thank the Water Research Commission (WRC; Project K5/2368//3) and the National Research Foundation of South Africa (Grant number: 90320) for funding this project. The South African Weather Services is thanked for providing the daily ambient temperature data. Professor Miles Markus from the University of the Witwatersrand is thanked for providing the Acanthamoeba strains used as positive PCR controls. Lastly the authors would like to thank Mr. Willem van Kerwel and the Welgevallen Experimental Farm of Stellenbosch University (South Africa) for the permission to set-up the solar pasteurization and rainwater tanks on the farm and for their assistance during the trials.

\section{Funding}

The Water Research Commission (WRC; Project K5/2368//3) and the National Research Foundation of South Africa (Grant number: 90320) funded this project.

\section{Availability of data and materials}

The datasets during and/or analysed during the current study is available from the corresponding author on reasonable request.

\section{Authors' contributions}

WK, SK and PD conceived and designed the experiments. PD performed the experiments and analyzed the data. WK and TE acquired funding for the study. WK and SK contributed reagents/materials/analysis tools. WK and PD wrote the paper. All authors edited the drafts of the manuscript and approved the final version of the manuscript.

\section{Competing interests}

The authors declare that they have no competing interests.

\section{Consent for publication}

Not applicable.

Ethics approval and consent to participate Not applicable.

\section{Author details}

${ }^{1}$ Department of Microbiology, Faculty of Science, Stellenbosch University, Private Bag X1, Stellenbosch 7602, South Africa. ${ }^{2}$ Faculty of Health and Applied Sciences, Namibia University of Science and Technology, 13 Storch Street, Private Bag 13388, Windhoek, Namibia.

Received: 19 July 2016 Accepted: 2 October 2016

Published online: 10 October 2016

\section{References}

1. Murad AA, Al Nuaimi H, Al HM. Comprehensive assessment of water resources in the United Arab Emirates (UEA). Water Resour Manag. 2007;21(9):1449-60.

2. Wheida $E$, Verhoeven R. An alternative solution of the water shortage problem in Libya. Water Resour Manag. 2007;21(6):961-82. doi:10.1007/s11269-006-9067-6.

3. O'Hara JK, Georgakakos KP. Quantify the urban water supply impacts of climate change. Water Resour Manag. 2008;22(10):1477-97. doi:10.1007/s11269-008-9238-8.

4. Ahmed W, Hodgers L, Sidhu JPS, Toze S. Fecal indicators and zoonotic pathogens in household drinking water taps fed from rainwater tanks in Southeast Queensland, Australia. Appl Environ Microbiol. 2012;78(1):219-26.

5. Lee JY, Bak G, Han M. Quality of roof-harvested rainwater-comparison of different roofing materials. Environ Pollut. 2012;162:422-9.

6. De Kwaadsteniet M, Dobrowsky PH, Van Deventer A, Khan W, Cloete TE. Domestic rainwater harvesting: microbial and chemical water quality and point-of-use treatment systems. Water Air Soil Poll. 2013;224(7):1-19.

7. Albrechtsen $\mathrm{H}$. Microbiological investigations of rainwater and graywater collected for toilet flushing. Water Sci Technol. 2002;46(6-7):311-6.

8. Simmons G, Jury S, Thornley C, Harte D, Mohiuddin J, Taylor M. A Legionnaires' disease outbreak: A water blaster and roof-collected rainwater systems. Water Res. 2008;42(6):1449-58.

9. Ahmed W, Huygens F, Goonetilleke A, Gardner T. Real-time PCR detection of pathogenic microorganisms in roof-harvested rainwater in Southeast Queensland, Australia. Appl Environ Microbiol. 2008;74(17):5490-6.

10. Ahmed W, Gardner T, Toze S. Microbiological quality of roof-harvested rainwater and health risks: a review. J Environ Qual. 2011:40(1):13-21.

11. Dobrowsky PH, Mannel D, De Kwaadsteniet M, Prozesky H, Khan W, Cloete TE. Quality assessment and primary uses of harvested rainwater in Kleinmond, South Africa. Water SA. 2014;40(3):401-6. 
12. Dobrowsky PH, De Kwaadsteniet M, Cloete TE, Khan W. Distribution of indigenous bacterial pathogens and potential pathogens associated with roof-harvested rainwater. Appl Environ Microbiol. 2014;80(7):2307-16.

13. Dobrowsky PH, Carstens M, De Villiers J, Cloete TE, Khan W. Efficiency of a closed-coupled solar pasteurization system in treating roof harvested rainwater. Sci Total Environ. 2015;536:206-14.

14. Department of Water Affairs and Forestry (DWAF). South African water quality guidelines 2nd Edition Volume 1: Domestic water use. Pretoria: CSIR Environmental Services; 1996

15. NHMRC, NRMMC. Australian drinking water guidelines (ADWG). Paper 6, national water quality management strategy. Canberra: National Health and Medical Research Council, National Resource Management Ministerial Council Commonwealth of Australia; 2011.

16. South African Bureau of Standards (SABS). South African national standards (SANS) 241: Drinking Water Quality Management Guide for Water Services Authorities. Annexure 1. ISBN 0-626-17752-9. 2005

17. Reyneke B, Dobrowsky PH, Ndlovu T, Khan S, Khan W. EMA-qPCR to monitor the efficiency of a closedcoupled solar pasteurization system in reducing Legionella contamination of roof-harvested rainwater. Sci Total Environ. 2016;15:662-70.

18. Lau HY, Ashbolt NJ. The role of biofilms and protozoa in Legionella pathogenesis: implications for drinking water. J Appl Microbiol. 2009;107(2):368-78.

19. Thomas V, Herrera-Rimann K, Blanc DS, Greub G. Biodiversity of amoebae and amoeba-resisting bacteria in a hospital water network. Appl Environ Microbiol. 2006;72(4):2428-38

20. Magnet A, Peralta R, Gomes T, Izquierdo F, Fernandez-Vadillo C, Galvan A, et al. Vectorial role of Acanthamoeba in Legionella propagation in water for human use. Sci Total Environ. 2015;505:889-95.

21. Liu H, Ha YR, Lee ST, Hong YC, Kong HH, Chung DI. Genetic diversity of Acanthamoeba isolated from ocean sediments. Korean J Parasitol. 2006:44(2):117-25.

22. Thomas V, Loret JF, Jousset M, Greub G. Biodiversity of amoebae and amoebae-resisting bacteria in a drinking water treatment plant. Environ Microbiol. 2008;10(10):2728-45.

23. Rodriguez-Zaragoza S. Ecology of free-living amoebae. Crit Rev Microbiol. 1994;20(3):225-41.

24. Rohr U, Weber S, Michel R, Selenka F, Wilhelm M. Comparison of free-living amoebae in hot water systems of hospitals with isolates from moist sanitary areas by identifying genera and determining temperature tolerance. Appl Environ Microbiol. 1998;64(5):1822-4.

25. Buse HY, Lu J, Struewing IT, Ashbolt NJ. Eukaryotic diversity in premise drinking water using 18S rDNA sequencing: implications for health risks. Environ Sci Pollut Res Int. 2013;20(9):6351-66.

26. Nagington JPG, Watson TJ, Playfair J, McGill Jones BR, Steele ADM. Amoebic infection of the eye. Lancet. 1974;304(7896):1537-40.

27. John DT. Opportunistically pathogenic free-living amebae. In: Kreier JP Baker JR, editors. Parasitic protozoa. San Diego, California: Academic Press, Inc:; 1993. p. 143-246.

28. Marciano-Cabral F, Cabral G. Acanthamoeba spp. as agents of disease in humans. Clin Microbiol Rev. 2003;16(2):273-307.

29. Coulon C, Collignon A, McDonnell G, Thomas V. Resistance of Acanthamoeba cysts to disinfection treatments used in health care settings. J Clin Microbiol. 2010;48(8):2689-97.

30. Neff RJ, Ray SA, Benton WF, Wilborn M. Methods in cell physiology. In: Prescott DM, editor. Induction of synchronous encystation (differentiation) in Acanthamoeba spp. New York: Academic; 1964. p. 55-83.

31. Fouque $E$, Héchard $Y$, Hartemann $P$, Humeau $P$, Trouilhé MC. Sensitivity of Vermamoeba (Hartmannella) vermiformis cysts to conventional disinfectants and protease. J Water Health. 2015;13(2):302-10.

32. Greub G, Raoult D. Microorganism resistant to free-living amoebae. Clin Microbiol Rev. 2004:17(2):413-33.

33. Pagnier I, Valles C, Raoult D, La Scola B. Isolation of Vermamoeba vermiformis and associated bacteria in hospital water. Microb Pathogenesis. 2015;80:14-20.

34. Mukherjee S, Liu X, Arasaki K, McDonough J, Galán JE, Roy CR. Modulation of Rab GTPase function by a protein phosphocholine transferase. Nature. 2011:477(7362):103-6.

35. Brüggemann H, Cazalet C, Buchrieser C. Adaptation of Legionella pneumophila to the Host environment: role of protein secretion, effectors and eukaryotic-like proteins. Curr Opin Microbiol. 2006;9(1):86-94.
36. Asare R, Santic M, Gobin I, Doric M, Suttles J, Graham JE, et al. Genetic susceptibility and caspase activation in mouse and human macrophages are distinct for Legionella longbeachae and L. pneumophila. Infect Immun. 2007:75(4):1933-45.

37. Horwitz MA. The Legionnaires' disease bacterium (Legionella pneumophila) inhibits phagosome-lysosome fusion in human monocytes. J Exp Med. 1983;158(6):2108-26.

38. Cazalet C, Gomez-Valero L, Rusniok C, Lomma M, Dervins-Ravault D, Newton $\mathrm{HJ}$, et al. Analysis of the Legionella longbeachae genome and transcriptome uncovers unique strategies to cause Legionnaires' disease. PLoS Genet. 2010;6(2):e1000851.

39. Allombert J, Fuche F, Michard C, Doublet P. Molecular mimicry and original biochemical strategies for the biogenesis of a Legionella pneumophila replicative niche in phagocytic cells. Microb Infect. 2013;15(14):981-8.

40. Molofsky AB, Swanson MS. Differentiate to thrive: lessons from the Legionella pneumophila life cycle. Mol Microbiol. 2004;53(1):29-40.

41. Fraser DW, Tsai TR, Orenstein W, Parkin WE, Beecham HJ, Sharrar RG, et al. Legionnaires' disease: description of an epidemic of pneumonia. N Engl J Med. 1977:297(22):1189-97.

42. Glick TH, Gregg MB, Berman B, Mallison G, Rhodes WWJ, Kassanoff I. Pontiac fever. An epidemic of unknown etiology in a health department: I. Clinical and epidemiologic aspects. Am J Epidemiol. 1978;107(2):149-60.

43. Schlech WF, Gorman GW, Payne MC, Broome CV. Legionnaires's disease in Caribbean: an outbreak associated with a resort hotel. Arch Intern Med. 1985;145(11):2076-9.

44. Dufresne SF, Locas MC, Duchesne A, Restieri C, Ismaïl J, Lefebvre B, et al. Sporadic Legionnaires' disease: the role of domestic electric hot-water tanks. Epidemiol Infect. 2012;140(1):172-81.

45. Borella P, Guerrieri E, Marchesi I, Bondi M, Messi P. Water ecology of Legionella and protozoan: environmental and public health perspectives. Biotechnol Annu Rev. 2005;11:355-80.

46. Mouchtouri V, Velonakis E, Tsakalof A, Kapoula C, Goutziana G, Vatopoulos A, et al. Risk factors for contamination of hotel water distribution systems by Legionella species. Appl Environ Microbiol. 2007;73(5):1489-92.

47. Duda S, Baron JL, Wagener MM, Vidic RD, Stout JE. Lack of correlation between Legionella colonization and microbial population quantification using heterotrophic plate count and adenosine triphosphate bioluminescence measurement. Environ Monit Assess. 2015;187(7):1-10.

48. Carter JT, Rice EW, Buchberger SG, Lee Y. Relationships between levels of heterotrophic bacteria and water quality parameters in a drinking water distribution system. Water Res. 2000;34(5):1495-502.

49. American Public Health Association (APHA). Standard methods for the examination of water and wastewater. Washington, DC: American Water Works Association and Water Pollution Control Federation; 1996.

50. Centers for Disease Control and Prevention (CDC). Procedures for the recovery of Legionella from the environment. National Center for Infectious Diseases. Division of Bacterial and Mycotic Diseases. Respiratory Disease Laboratory Section. US: US Department of Health and Human Services; 2005.

51. Schets FM, Italiaander R, Van Den Berg HHJL, de Roda Husman AM. Rainwater harvesting: quality assessment and utilization in The Netherlands. Water Health. 2010;8(2):224-35.

52. Edelstein PH, Edelstein MA. Comparison of three buffers used in the formulation of buffered charcoal yeast extract medium. J Clin Microbiol. 1993;31(12):3329-30.

53. Ndlovu T, Le Roux M, Khan W, Khan S. Co-detection of virulent Escherichia coli genes in surface water sources. PLoS One. 2015;10(2):e0116808.

54. Dobrowsky PH, Lombard M, Cloete WJ, Saayman M, Cloete TE, Carstens M et al. Efficiency of microfiltration systems for the removal of bacterial and viral contaminants from surface and rainwater. Water Air Soil Pollut. 2015;226(3):1-14

55. Delgado-Viscogliosi P, Solignac L, Delattre J-M. Viability PCR a cultureindependent method for rapid and selective quantification of viable Legionella pneumophila cells in environmental water samples. Appl Environ Microbiol. 2009:75(11):3502-12.

56. Chang CW, Lu LW, Kuo CL, Hung NT. Density of environmental Acanthamoeba and their responses to superheating disinfection. Parasitol Res. 2013;112(11):3687-96.

57. Miyamoto H, Yamato H, Arima K, Fujii J, Maruta K, Izu K, et al. Development of a new semi nested PCR method for detection of Legionella species and its application to surveillance of Legionellae in Hospital cooling tower water. Appl Environ Microbiol. 1997;63(7):2489-94. 
58. Herpers BL, de Jongh BM, van der Zwaluw K, van Hannen EJ. Real-time PCR assay targets the 23S-5S spacer for direct detection and differentiation of Legionella spp. and Legionella pneumophila. J Clin Microbiol. 2003;41(10):4815-6.

59. Qvarnstrom Y, Visvesvara GS, Sriram R, da Silva AJ. Multiplex real-time PCR assay for simultaneous detection of Acanthamoeba spp., Balamuthia mandrillaris, and Naegleria fowleri. J Clin Microbiol. 2006;44(10):3589-95.

60. Kuiper MW, Valster RM, Wullings BA, Boonstra H, Smidt H, Van Der Kooij D. Quantitative detection of the free-living amoeba Hartmannella vermiformis in surface water by using real-time PCR. Appl Environ Microb. 2006;72(9):5750-6.

61. Chen NT, Chang CW. Rapid quantification of viable Legionellae in water and biofilm using ethidium monoazide coupled with real-time quantitative PCR. J Appl Microbiol. 2010;109(2):623-34.

62. Hellemans J, Mortier G, De Paepe A, Speleman F, Vandesompele J. qBase relative quantification framework and software for management and automated analysis of real-time quantitative PCR data. Genome Biol. 2007;8(2):R19.

63. Schmittgen TD, Livak KJ. Analyzing real-time PCR data by the comparative CT method. Nat Protoc. 2008;3(6):1101-8.

64. Bustin SA, Benes V, Garson JA, Hellemans J, Huggett J, Kubista M, et al. The MIQE guidelines: minimum information for publication of quantitative realtime PCR experiments. Clin Chem. 2009;55(4):611-22

65. Ahmed W, Brandes H, Gyawali P, Sidhu JPS, Toze S. Opportunistic pathogens in roof-captured rainwater samples, determined using quantitative PCR. Water Res. 2014;53:361-9.

66. Wang $\mathrm{H}$, Edwards M, Falkinham JO, Pruden A. Molecular survey of the occurrence of Legionella spp., Mycobacterium spp., Pseudomonas aeruginosa, and amoeba hosts in two chlorinated drinking water distribution systems. Appl Environ Microbiol. 2012;78(17):6285-94.

67. Ulrich MP, Norwood DA, Christensen DR, Ulrich RL. Using real-time PCR to specifically detect Burkholderia mallei. J Med Microbiol. 2006;55(5):551-9.

68. Sommer B, Marino A, Solarte Y, Salas ML, Dierolf C, Valiente C, et al. SODIS- an emerging water treatment process. J Water SRT - AQUA. 1997;46(3):127-37.

69. Serrano-Suárez A, Dellundé J, Salvadó H, Cervero-Aragó S, Méndez J, Canals $\mathrm{O}$, et al. Microbial and physicochemical parameters associated with Legionella contamination in hot water recirculation systems. Environ Sci Pollut Res Int. 2013;20(8):5534-44. doi:10.1007/s11356-013-1557-5.

70. Weekers PH, Bodelier PL, Wijen JP, Vogels GD. Effects of grazing by the freeliving soil amoebae Acanthamoeba castellanii, Acanthamoeba polyphaga, and Hartmannella vermiformis on various bacteria. Appl Environ Microbiol. 1993;59(7):2317-9.

71. Velonakis EN, Kiousi IM, Koutis C, Papadogiannakis E, Babatsikou F, Vatopoulos A. First isolation of Legionella species, including L. pneumophila serogroup 1, in Greek potting soils: possible importance for public health. Clin Microbiol Infec. 2010;16(6):763-6.

72. Saint CP, Ho L. A PCR test for the identification and discrimination of Legionella longbeachae serogroups 1 and 2. J Microbiol Meth. 1999;37(3): 245-53.

73. Conza L, Casati S, Gaia V. Detection limits of Legionella pneumophila in environmental samples after co-culture with Acanthamoeba polyphaga. BMC Microbiol. 2013:13(1):2-6.

74. Hamilton KA, Ahmed W, Palmer A, Sidhu JPS, Hodgers L, Toze S, Haas CN. Public health implications of Acanthamoeba and multiple potential opportunistic pathogens in roof-harvested rainwater tanks. Environ Res. 2016:150:320-7.

75. Gruas C, Álvarez I, Lara C, García CB, Savva D, Arruga MV. Identification of Legionella spp. in environmental water samples by ScanVIT-Legionella ${ }^{T M}$ method in Spain. Indian J Microbiol. 2013;53(2):142-8.

76. Rizzardi K, Winiecka-Krusnell J, Ramliden M, Alm E, Andersson S, Byfors S. Legionella norrlandica sp. nov., isolated from the biopurification systems of wood processing plants. Int J Syst Evol Micr. 2015;65(2):598-603.

77. Adeleke AA, Fields BS, Benson RF, Daneshvar MI, Pruckler JM, Ratcliff RM, et al. Legionella drozanskii sp. nov., Legionella rowbothamii sp. nov. and Legionella fallonii sp. nov.: three unusual new Legionella species. Int J Syst Evol Micr. 2001;51(3):1151-60.

78. Alleron L, Merlet N, Lacombe C, Frère J. Long-term survival of Legionella pneumophila in the viable but nonculturable state after monochloramine treatment. Curr Microbiol. 2008;57(5):497-502. doi:10.1007/s00284-008-9275-9.

79. Dusserre E, Ginevra C, Hallier-Soulier S, Vandenesch F, Festoc G, Etienne J, et al. A PCR-based method for monitoring Legionella pneumophila in water samples detects viable but noncultivable Legionellae that can recover their cultivability. Appl Environ Microbiol. 2008;74(15):4817-24. doi:10.1128/AEM.02899-07.

80. Chang SL. Resistance of pathogenic Naegleria to some common physical and chemical agents. Appl Environ Microb. 1978;35(2):368-75.

81. Thomas V, McDonnell G, Denyer SP, Maillard JY. Free-living amoebae and their intracellular pathogenic microorganisms: risks for water quality. FEMS Microbiol Rev. 2010;34(3):231-59.

82. Puzon GJ, Lancaster JA, Wylie JT, Plumb IJ. Rapid detection of Naegleria fowleri in water distribution pipeline biofilms and drinking water samples. Environ Sci Technol. 2009;43(17):6691-6.

83. Bartram J, Chartlier Y, Lee JV, Pond K, Surman-Lee S. Legionella and the prevention of Legionellosis. Geneva: World Health Organization; 2007.

84. Temmerman $\mathrm{R}$, Vervaeren $\mathrm{H}$, Noseda B, Boon N, Verstraete W. Necrotrophic growth of Legionella pneumophila. Appl Environ Microb. 2006;72(6):4323-8.

85. Storey MV, Winiecka-Krusnell J, Ashbolt NJ, Stenström TA. The efficacy of heat and chlorine treatment against thermotolerant Acanthamoebae and Legionellae. Scand J Infect Dis. 2004;36(9):656-62.

86. Bartie C, Venter S, Nel L. Identification methods for Legionella from environmental samples. Water Res. 2003;37(6):1362-70.

87. Deacon R. Prevalence of Legionella strains in cooling towers and legionellosis cases in New Zealand. J Environ Health. 2013;75(6):82.

88. Graham FF, White PS, Harte DJG, Kingham SP. Changing epidemiological trends of legionellosis in New Zealand 1979-2009. Epidemiol Infect. 2012;140(8):1481-96. doi:10.1017/S0950268811000975.

89. Szewzyk U, Szewzyk R, Manz W, Schleifer KH. Microbiological safety of drinking water. Annu Rev Microbiol. 2000;54(1):81-127.

90. Marciano-Cabral F, Cabral GA. The immune response to Naegleria fowleri amebae and pathogenesis of infection. FEMS Immunol Med Mic. 2007;51(2):243-59.

\section{Submit your next manuscript to BioMed Central and we will help you at every step:}

- We accept pre-submission inquiries

- Our selector tool helps you to find the most relevant journal

- We provide round the clock customer support

- Convenient online submission

- Thorough peer review

- Inclusion in PubMed and all major indexing services

- Maximum visibility for your research

Submit your manuscript at www.biomedcentral.com/submit

) Biomed Central 